\title{
Jegyzőkönyv \\ az MTA Regionális Tudományos Bizottság 2005. október 26-án tartott ülésről
}

1. Beszámoló a Bizottság 2002-2005 közötti müködésről. Előadó: Rechnitzer János elnök.

A szóbeli beszámolóhoz két hozzászólás történt. Enyedi György kiemelte, hogy a bizottság sikerrel múkoodött együtt más akadémiai bizottságokkal, ez jelzi a tudományterület nyitottságát és elfogadottságát. Hangsúlyozta, hogy az üléseken komoly és alapos szakmai témák kerültek megvitatásra, így a müködés során folyamatosan érvényesült a magasfokú szakmaiság. Horváth Gyula kiegészitette a beszámolót azzal, hogy a Bizottság kezdeményezte a Magyar Regionális Tudomânyi Társaság alapítását, továbbá kiemelést érdemel, hogy Bailly professzort 2004-ben az MTA külső tagjává választotta.

Az elnök ismertette Kovács Géza professzor levelét, amiben idős korára és betegségére való tekintettel lemond a bizottsági tagságáról. A bizottság regisztrálta Kovács professzor úr bejelentését, felkérte a leköszönő elnököt, hogy levélben köszönje meg Kovács professzor kiemelkedő munkáját.

A Bizottság a 2002-2005. közötti 6. ciklusának beszámolóját a jelen lévő tagság egyhangúan elfogadta.

Az elnök megkőszönte az elnökség nevében a támogatást és az aktivitást, s ezzel a vezetöség megbízása lejárt.

2. Az ủlés vezetését Enyedi György akadémikus vette át. Megállapította, hogy a 40 regisztrált köztestületi, választásra jogosult tagból 23 fő van jelen, így az 57,5\%-os részvétel a Bizottság megválasztását a 2005-2008 közötti 7. ciklusra lehetôvé teszi. Ismertette, hogy a tagság körében végzett előzetes felmérés alapján megerỏsítést nyert, hogy a különböző tisztségekre az alábbi személyeket javasoljuk: elnök: Rechnitzer János DSc, alelnök: Lengyel Imre DSc, titkár: Izsák Eva PhD.

A jelenlévő tagok elfogadták a választás elókészítését, és nyílt, egyhangú szavazással elnöknek: Rechnitzer Jánost, alelnöknek: Lengyel Imrét, titkárnak: Izsák Évát választották.

Enyedi György ismertette, hogy a Bizottság tagjai hivatalból lehetnek az MTA tagjai, a tudomány doktorai, és tagok válaszhatók a tudomány kandidátusi, PhD fokozattal rendelkezők közül arányosan. A regisztrált köztestületi tagok alapján javasolta, hogy a kandidátusok és PhD tagok közül hat fơt lenne célszerủ bizottsági taggá választani.

A jelenlévők elfogadták a javaslatot, hogy hat fóvel egészüljön ki a Bizottság a nevezett körbỏl. A jelenlévők javaslatot tettek a megválasztható személyekre. A szavazó listára a következőket kerültek fel: Hardi Tamás, Faragó László, Kocziszky György, Korompai Attila, Bernek Ágnes, G. Fekete Ágnes, Baranyi 
Béla, Káposzta József, Ormosy Viktor, Rédei Mária, Varga Attila, Gulyás László, Fleisher Tamás.

A tagok titkos szavazásának eredménye a következö: Hardi Tamás 15, Faragó László 14, Korompai Attila 13, Kocziszky György 12, Bernek Ágnes 13, G. Fekete Ágnes 11. Baranyi Béla 8, Káposzta József 9, Ormosy Viktor 8, Rédei Mária 7, Varga Attila 8, Gulyás László 4, Fleisher Tamás 6.

A szavazás alapján Hardi Tamás 15, Faragó László 14, Korompai Attila 13, Kocziszky György 12, Bernek Ágnes 13, G. Fekete Ágnes 11 került be Bizottság tagjai közé.

3. Lengyel Imre ismertette a tervezett regionális tudományi mesterszak koncepcióját. A koncepcióhoz számos észrevétel érkezett. A tagság támogatja, hogy jelenjen meg több tudományterületre tervezett mesterszakokban a regionális tudományi szakmai törzsanyag. Ennek tartalmáról vita folyt, így növelni kell a földrajzi ismerteket, a vállalkozások és a tér kapcsolatait, a tervezés elméleti megalapozását közvetítő tudásanyag arányát, átfogóbbá kell tenni a regionális politika tartalmát, növelni érdemes a környezettudományi elemeket, a térelméleti megalapozást, a nemzetközi gazdasági folyamatokról szóló részeket, valamint alaposabb elemzési módszertani és több társadalomtudományi elemre lenne szükség. A vita felvetette, hogy egy önálló regionális tudományi mesterképzésre lenne szükség, azonban ennek a beágyazása a jelenlegi tudományi rendszerben, mind a minősítő szervezetnél (MAB), mind a felsőoktatási intézményeknél nem könnyủ, számos esetben nem lehetséges.

A Bizottság javasolja, hogy kerüljön kidolgozásra egy olyan mesterszak, amely a közgazdasági képzéshez kapcsolódjon, és abban erőteljesen jelenjenek meg a regionális tudományi elemek. A "helyi és regionális gazdaságfejlesztési mesterszak” megnevezést a Bizottság elfogadhatónak tekinti, annak szakmai tartalmában további munkálkodást lát szükségesnek. Továbbá javasolta, hogy más, a regionális tudományi kérdésekkel is foglalkozó mesterszakoknál is érvényesüljön a szakmaiság.

Budapest, 2005. október 26.

Izsák Éva titkár 